\title{
How is Academic Performance Affected by Delay in Student Loan Disbursement in Kenyan Universities? A Case Study of Kenyatta University
}

\author{
Alvin Bomer ${ }^{1}$, Xiaoguang Liu ${ }^{1}$, Wanjiru Ruth Irungu ${ }^{1} \&$ Wambui Ann Wanjiru ${ }^{1}$ \\ ${ }^{1}$ College of Public Administration, Nanjing Agricultural University, China \\ Correspondence: Xiaoguang Liu, College of Public Administration, Nanjing Agricultural University, China. \\ Tel: 86-137-7064-1997. E-mail: liuxg@njau.edu.cn
}

Received: October 31, 2020

Accepted: January 4, $2021 \quad$ Online Published: January 24, 2021

doi:10.5539/hes.v11n1p121

URL: https://doi.org/10.5539/hes.v11n1p121

\begin{abstract}
The current research focused on the impact of delayed loan disbursement on performance. The study focused on Kenyatta University, situated in Nairobi, Kenya. In the study, the variables of class attendance, personal expenses, and course registration were evaluated as the main factors that impacted student performance due to delayed loans. A sample of 196 students were randomly selected from the population to take part in the study. The students were given questionnaires regarding higher education loan disbursement and the major variables being evaluated. The results revealed that students who experienced loan delays had problems covering their personal expenses, registering for courses, and attending classes. These challenges had a significant impact on the final performance in terms of grade point average. The study recommended that the government needs to release funds to the Higher Education Loans Board on time to facilitate fast disbursement of loans to the students. Also, it recommended closer collaboration between the Higher Education Loans Board and University administrations to ensure that students who are awaiting their loans are not denied to attend classes and register for courses.
\end{abstract}

Keywords: disbursement, higher education loans board, academic performance

\section{Introduction}

Education is an essential asset and requirement in many job opportunities. Students can divert attention to the area of interest through higher education, which boosts creativity and innovation (Martín, Potočnik \& Fras, 2017). However, not all students can afford or access the education they want due to inadequate funds. A substantial number of students have greatly depended on the loans to fund their university education (Oketch, 2016; Sieg \& Wang, 2018). In some instances, these loans' disbursement can be delayed, impacting the students' academic performance. In some of the institutions and programmes, students can only be allowed to attend class or do examinations if they have completed fees payment. In this case, such delayed disbursement denies the student the opportunity to attend classes in time and sometimes even miss taking examinations. Besides, the loans also enable students from low-income families to access learning resources such as course books (Msigwa, 2016). If loans are delayed, students may have difficulty accessing learning materials, which are critical in improving academic performance. When students lack timely disbursement, they tend to look for extra jobs to complement their funding of academic programs. Therefore, they will not have enough time to study because free time is occupied with other work, limiting the time spent or available for studying. In the end, this causes poor academic performance. In this respect, the purpose of this research is to determine various ways through which delayed loan disbursement impact determinants of academic performance such as class attendance, course unit registration, and student expenses

\subsection{Background}

Student loan programs currently exist in many countries, both developing and developed (Joensen \& Mattana, 2019); Albrecht \& Ziderman, 1992; Woodhall, 1991). From a global perspective, in most developed countries such as the United States (U.S.), funding higher education is critical to meet the market's required skills. Kallison and Cohen (2010) argued that despite government support through funding diminishing in the United States, the growing technology influence and globalization requires a highly educated workforce. However, not all people can 
privately afford higher education hence the need for funding with the institutions responsible for managing the loans being accountable. Maintaining academic freedom in choosing programs and accountability standards is necessary for the long-term realization of the loans' success. In the recent past, there has been a trend regarding student aid from an increasing number of beneficiaries in the United States. Most of the students receive grants as a primary funding source and federal loans (Sandy \& Kathleen, 2012). Despite the growth rate, the past few years have seen a drop in the number of beneficiaries and the amount spent on the loans disbursed in the U.S (Sandy \& Kathleen, 2012). Besides, other factors such as enrolments also influenced the amount an individual gets in funding. Based on Sandy and Kathleen (2012) evaluation, the students receive an average of \$13218 in financial aid, where the grants cover about $\$ 3932$ while the federal loans are about $\$ 5056$ (Sandy \& Kathleen, 2012).

In a research by Tangkitvanich and Manasboonphempool (2010), the authors concluded that since the introduction of the Student Loan Fund of Thailand in 1996. Many students have accessed higher education in colleges and universities, making the society transition from elitists to a mass institution of learned people in the first ten years of operation. In this case, the funding in the same period sponsored 2.6 million students who utilized an estimated value of about $\$ 5.7$ billion. According to a study conducted by Jianguo \& Rong (2011), in China, since the launch of the policy on higher education expansion in 1999, higher education in China shifted from elite education to mass education. The Chinese government reformed the previous policies for free tuition in the process of promoting mass higher education. Implementing these macro-policies created a real problem in assisting the increasing number of needy students completing their higher education. China launched a student loan policy to address this problem (Jianguo \& Rong, 2011).

In Africa, most countries established a department for higher education student loans to distribute and recover loans from beneficiaries. Some of the states consider funding higher education as a cost-sharing process. For instance, in Tanzania, parents and students hold that funding higher education should be a state responsibility (Chatama, 2014). Tanzania established a Higher Education Student Loans Board (HESLB) department, which oversees higher education financing for students who attend universities. However, due to the growing number of students who depend on the loan, the exclusion criteria have led to reduced students sponsored, and in some instances, delayed loan disbursements (Chatama, 2014). In a study by Nyahende (2013), the author assessed student loans' success in higher education to be highly satisfactory. Some of the indicators of this success, particularly in Tanzania, include increasing enrolment in higher learning institutions and effective recovery of debts (Nyahende, 2013). Therefore, with an effective financial framework for managing and recovering the loan, higher education's affordability is critical in its successful economic progress. In this respect, Nyahende (2013) recommended that the institutions also include evaluation criteria of the loan applicants' economic state and future employment to make it more effective. An enforceable legal framework can enhance delayed debt recovery to avoid disbursing disruption to other upcoming beneficiaries.

Kenya strongly recommended that higher education offers student loans as early as 1952. Financial aid was provided for students pursuing education in countries such as India, Russia, the U.S.A., Great Britain, and the United States under the Higher Education Loans Fund (HELF) (Otieno 2004). The government later scrapped the loan program and decided to finance higher education after gaining independence in 1964, using grants to improve university enrollment and fostering economic growth. The move was motivated by the suggestion of the Kenya Education Commission (K.E.C.) that having highly qualified professionals would make a smooth transition from the colonial era possible.

A few years later, the government started again considering reactivating the traditional student loan system to serve Kenyan students because of the increasing enrollment and slow economic growth due to the oil shocks experienced. The loan program was reintroduced and decrease the grants to manage the economic pressures. After receiving applications, the government financed the loan program and disbursed the funds to eligible students (Johnstone, 2015). The Ministry of Education (MoE) administered the program under the Loan Disbursement and Recovery Unit (LDRU). Though a guiding policy was not set up at the time, key roles were given to the unit to ensure access, reduce inequality, reduce drop-out rates, encourage the right career choices, and complement the government's efforts by growing enrollment in tertiary institutions.

Failure to consider a rise in enrollment and weak program management compromised its performance, and the loan repayment rate was substantially low. Several explanations were given as reasons for the program's failure. Firstly, the fact that it failed to embrace precautionary measures to mitigate against default affected loan recovery. Since it was a department under the Ministry of Education, it also included employees who were not adequately trained in the recovery of loan administration (Otieno 2004; Johnstone, 2015).

However, the legal challenges were addressed by the creation of a Higher Education Loans Board (HELB) 
through a parliamentary act in 1995 to ensure smooth administration of loans and a framework for recovery (Otieno, 2004; Johnstone, 2015). As a result of increased enrolment in high education institutions, the board significantly increased loan repayment because, unlike in the past, it also issued loans to students at private universities. As beneficiaries, the board also enlisted other national training colleges. This trend challenged the assumption that privately-financed students came from wealthy families

\subsection{Scope of the Study}

The study was conducted in one of the leading universities in Kenya. The country's choice was based on the fact that Kenya is among the developing countries facing challenges in funding its higher education. The problem was caused by the free secondary education, which came into place in 2008 . The policy led to a higher enrolment in secondary schools resulting in a greater number of students joining colleges and universities. As a result, HELB could not meet the high number of funding applications. These challenges have led to constant delays in the disbursement of student loans. Also, there has been a challenge in loan recovery from the previous beneficiaries, coupled with delayed budgetary allocations from the national treasury. Kenyatta University was chosen due to its large number of students benefiting from government financial aid through HELB.

\subsection{Problem Statement}

Despite the benefits of the loans, the main challenge has been delayed disbursement, which affects the students' education continuity and performance. Disbursement delays result from the low rate of recovery of government loans and the rising student financial requirements, which is more than the government (Abdul, 2015). In most cases, students from poor backgrounds are affected. In this respect, such delays are bound to affect the performance of students. In evaluating Thailand's student loans, Tangkitvanich and Manasboonphempool (2010) assert that delays in loan disbursement and low recovery rate contributed to the low enrollment in higher education. This indicates that students, especially those who are not beneficiaries of the loan, are less likely to enroll in the university.-

Even in developed countries such as the United States, the challenge of loans has contributed to delay in the disbursement of funds, affecting the students' studies. For instance, research by Cooley (2013) indicated that the debt from student loans has exceeded 1 trillion U.S. dollars and is mainly due to a lack of checking promissory notes attached when applying and entering into a contract for the loan application. In this respect, such high levels of student loan debt make funds inaccessible to some of the students, causing a reduction of enrolment rate due to bankruptcy of the student aid (Cooley, 2013). Therefore, this indicates that defaulting in paying loans among beneficiaries is a major contributing factor in the delay of disbursement of loans.

Most of the studies have focused on finding out what causes delays and the concept of student loan debts and have also come up with recommendations on improving the current financial aid situation to assist other students in accessing higher education. However, there is little research on the direct impact of loan delays on the students' academic performance. In this light, the study contributes to this literature gap to determine how delayed disbursement of the loans further causes a negative impact on academic performance. Indicators such as class attendance, course/unit registration, and student expenses will be reviewed.

\subsection{Research Questions}

The research question is what the impact of delayed loan disbursement on the academic performance of students is, and how it influences:

1. Students' class attendance

2. Students' course unit registration

3. Students' expenses

\subsection{Objective}

To determine the impact of delayed loan disbursement on the academic performance (grade point average) of students through the assessment of class attendance, course, and unit registration, as well as student expenses.

\section{Literature Review}

In a review of previous literature on delays in loan disbursement and how it affects students' performance, four main areas were identified, including class attendance, course/unit registration, student expenses, and grade point average. This literature review will address these four areas to evaluate past scholarly works on the subject and identify the existing gap. Further, the study will explore a theoretical perspective of educational theory applicable to student funding and its relation to academic performance. 


\subsection{Class Attendance}

Class attendance can significantly be affected by the availability of funds. As demonstrated by Dynarski (2000), an evaluation of the impact of Georgia's Helping Outstanding Pupils Educationally (HOPE) scholarship shows that increased expenditure in funding students increased college attendance. In the study, which involved middle and high-income youths, the author found out that through the state's scholarship program, class attendance increased from 7 to $7.9 \%$ among 18 and 19-year-olds (Dynarski, 2000). In every $\$ 1000$ spent on student aid, there was a correspondence increase of 3.7 to $4.2 \%$ of students in class attendance. Therefore, the study indicated a direct impact of the student aid through loans or grants in an increment of student performance. The implication is that if funds are provided in time to students to cater their education and expenses, then the rate of class attendance will be high, thus high academic performance (Dynarski, 2000). Moore (2004) identified that in classes where class attendance was emphasized, students rarely missed lectures, and their grades were high. This is despite the fact that not extra credits were awarded for the presence in lectures. On the other hand, low-class attendance contributed significantly to low grades. Therefore, the study implies that schools and government policies should be focused on building developmental education to encourage student performance. This can be through making the learners have high expectations, change their attitudes towards education, and understand the importance of good performance in various disciplines. Through this study, the importance of class attendance is directly implicated in high academic achievement, which is assessed through test scores.

In another study, Latif and Miles (2013) assert the importance of class attendance and academic performance. In this research, a panel analysis of data from a sample of Canadian students undertaking a course of statistics was used to evaluate the behavior of class attendance and correlation with the performance in the examinations. In this study, other possible variables that could affect the grades, including the student's ability and effort to study, were controlled. In this respect, the findings indicated that class attendance significantly improved the students' grades with the other elements' control. Considering some of the assignments were conducted online, the authors also recognized that completion in time and attending the classes have an independent influence on grades achieved (Latif \& Miles, 2013). Therefore, the study has a strong implication on the importance of attending class, especially in technical subjects such as statistics. Thatcher, Fridjhon \& Cockcroft (2007); Stanca (2006); Dey (2018); Alexander \& Hicks (2016) ; Landin \& Pérez, (2015); Aden, Yahye \& Dahir (2013) ; and Schmulian \& Coetzee (2011) also found same results in their study.

\subsection{Unit/Course Registration}

Delayed financial aid to students who depend on loans and grants to study can impact the period of unit/course registration in various courses and, ultimately, the students' performance. In a study by Gurantz (2016), the author focused on unit registration among students while also considering increasing students to a few available classes. In this case, the sample was taken from California. The author identified some of the economic factors that may affect the period of registration as early, middle, or late, which might affect not only enrollment to colleges but also the availability of the learning resources. Some economic factors include budget cuts, especially after the great recession of financial aid to students. As a result, varying levels of delays and intensity in the unit registration process influence students' choice regarding the type of course they undertake. In some instances, some students could miss out on seat availability due to delayed registration, which affected the graduation and transfer requirements (Gurantz, 2016). Therefore, the implication is that lack of funds can affect the period of registering courses, which in turn affects the retention rate and enrollment of the students in college. It is recommended that the government policies on funding education provides the overcrowding condition and enhance students' timely registration. The same findings were found in Shriner's (2014) study.

In a quantitative study by Smith (2014), the author also identified that the timely registration of college units could improve the students' academic performance and the probability of retaining first-time learners in colleges and universities. Using logistic regression models on the study of freshmen samples of 6739 in 2011 and 4454 in 2012 fall periods, there was a strong statistical significance of the unit registration period associated with the retention of first-time students and their academic performance as well. This was determined based on the decided students who registered early, performed highly in the G.P.A. averages at the end of the semester, and were likely to return to the course the next semester. For the undecided students, late registration, the low retention rate, and academic performance were affected negatively (Smith, 2014). Therefore, unit registration affects the performance of the student, as well. In some instances, students might withdraw from some of the courses as well. Mangold et al. (2002) suggest a mentoring program for block registration of students across universities and colleges to improve students' retention and academic success. This improves not only persistence but also timely course registration and a positive impact on academic performance. Therefore, these studies indicate unit registration and financial resources as significant in student learning outcomes among 
students. Fujiwara, K. (2013); Fujiwara, K. (2013); Hale \& Bray (2011); and Smith et al. (2010) also found registration of unit impact academic performance.

\subsection{Student Expenses}

Singell (2004) uses the University of Oregon data to break down cash related guide's effect on upkeep net of surprisingly point by point enrollee characteristics and adjusted on covertly enrollee properties recognized by commonly exhibiting support and selection. The results show that need-and authenticity-based guides increase support in a general sense, yet these effects are uneven by assurance and change with need and limit (Singell, 2004). This examination is upgraded using diagram data on non-retainees that show that the decision to drop out depends on money-related challenges. The disclosures recommend that growing reliance on unsubsidized and merit-based guide by government and schools has cut down the relative graduation paces of needy students.

In a recent article by Young (2020), the author indicates that student loans are significantly important in helping students with tuition fees and other expenses such as housing and supplies. In this case, the loans are a debt to help students get through college by getting extra funds. The author indicates that the loans provided are under a framework in which the department of education allows students to use the funds to help with expenses to increase the spare time for studying (Young, 2020). The funds are designated to help with issues associated with the cost of attending classes and school, including transportation, books, computers, and other supplies needed for studying. In this respect, the author shows the significant role that funds for students' expenses play in facilitating school attendance and proper learning, which may positively affect academic performance. Other studies such as Weaver (2013), Fosnacht, \& Dong (2013, November), Nyakunga (2011), and Adzido et al. (2016) found student personal expenses had an impact on academic performance.

\subsection{Grade Point Average}

Curs and Harper (2012) noted that most studies focus on class attendance, retention rates, and the possibility of graduating students receiving financial aid. However, there is little research to focus specifically on how financial aid influences students' performance based on their grade point average. In this respect, the authors studied the impact of the financial aid provided to students in the freshman year by evaluating the G.P.A. at the end of the first year of study. The authors used causal estimation techniques combined with a regression continuity analysis to determine the relationship between the study variables of G.P.A. and financial aid. Based on the results, first-year students' financial aid programs directly impact their performance based on first-time learners' G.P.A. Further, the causal impact was determined to be positive and significant, which means that the students scored higher in G.P.A. averages when they received financial aid, especially over time (Curs \& Harper, 2012). Therefore, the results entail an implication that financial aid provided in a timely manner can significantly motivate students to continue pursuing academics and achieve success in their examinations. In this case, student performance and positive attitudes towards academics are essential for excelling in other spheres of life. This is predetermined by the availability of funding to help with student expenses and tuition coverage.

In another study by Coria and Hoffman (2015), assessing the relationship between college students' funding through loans and grants in relation to academic achievements also indicated how the lack of funding affects grades. In this case, the authors explored measures of the academic achievements among the California community college students with the amount of financial aid received. Using records of about 11956 students and analysis using linear regression and ANOVA, the results indicated that students with higher financial needs had lower academic scores. The implication is that students who lacked enough funding for their learning activities and living expenses were more likely to perform lowly in G.P.A. scores at the end of the year compared to those whose most needs were met. In this respect, the authors suggest that governments should include policies to meet students' needs through the timely provision of financial aid and valuation of students' needs to motivate and help them achieve higher scores in the G.P.A. results. Also, institutions should enhance resource availability by changing practices to enhance higher academic performance among students with high unmet needs in higher learning institutions (Coria \& Hoffman, 2015). Though the focus on one college was used, the implications can also be applied to other students undergoing the same struggles in meeting their needs and balancing with education requirements, affecting how they perform during tests. In this respect, the study provides critical information on how students may have lower academic performance due to financial aid challenges.

\subsection{Literature Gap}

Numerous studies have focused on the effect of class attendance, unit registration, and student expenses. The studies evaluated above have clearly shown that these variables have a significant impact on student performance. However, little has been done to determine the impact of delayed loan disbursements on student academic 
performance. The current study, therefore, seeks to evaluate the relationship between the delayed loan and student performance. In this context, the study evaluates how delayed loan disbursement affects academic performance through the mediator variables of class attendance, unit/course registration, and personal expenses.

\subsection{Theoretical Perspective}

The main theory used in this study is the human capital theory. The theory states that education is an investment for the country to realize its economic benefits, especially in a capitalist society (Gillies, 2017). In this theory, formal education is essential to help in improving the population's capacity to be productive in the future, through the increment of economic productivity and capability, as well as building cognitive skills, a country's investment in education results in higher productivity of the country as well (Holden \& Biddle, 2017). In this regard, adding innovation and creative investments in education has resulted in most Western countries' economic power. In this respect, most states increase education funding to produce a productive workforce and creative minds for the states' economic stability and growth. One of the ways to support education has been to make it a public good that is basic by subsidizing the expenses. Besides, the provision of loans and grants to students in higher education earning institutions has helped in the process.

\subsection{Conceptual Framework}

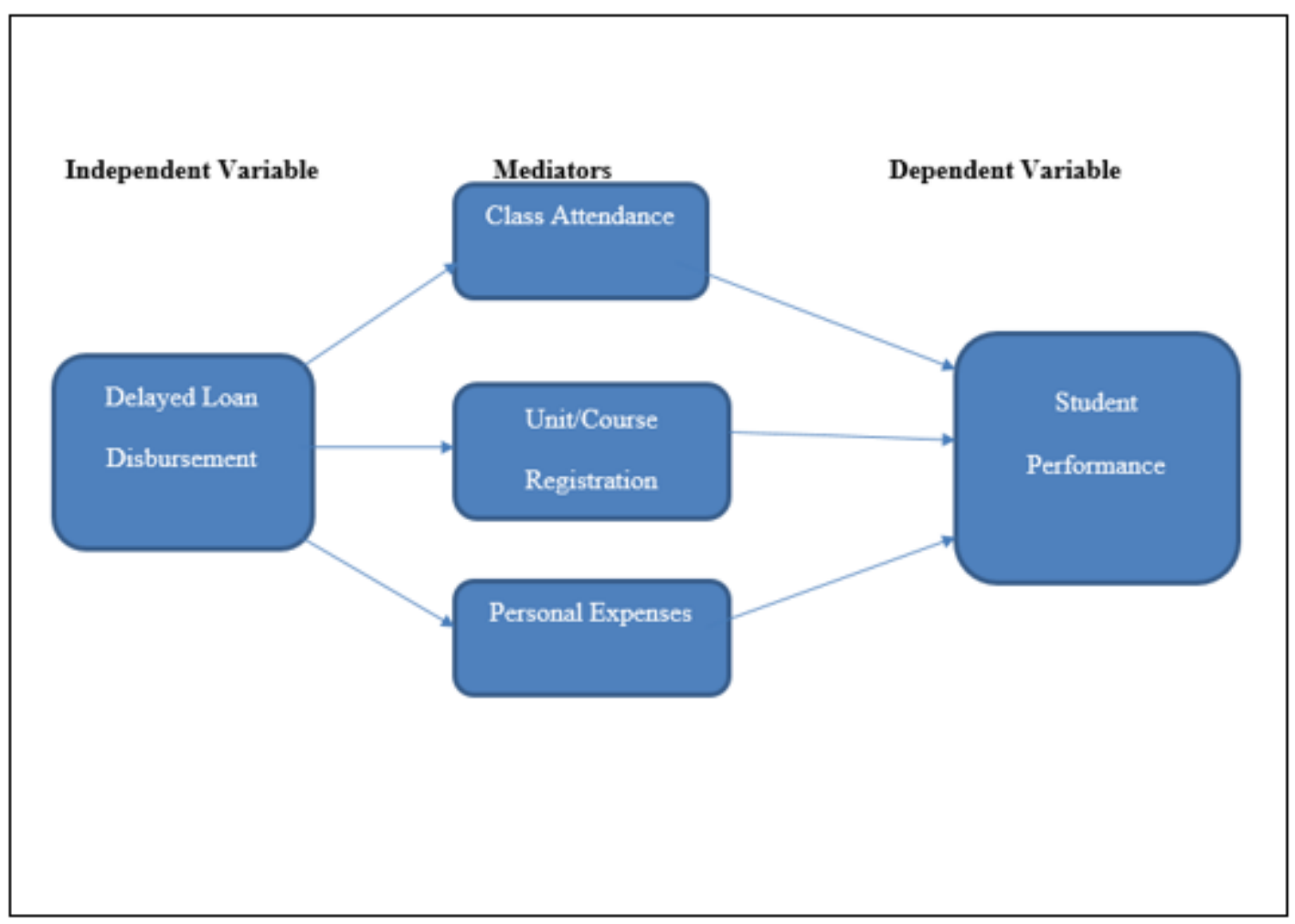

Figure 1. Conceptual Framework

Fig. 1 above shows the conceptual framework for the study variables. The study's independent variable is the delayed loan disbursement and the dependent variable is student performance, which is measured using G.P.A. The study also has a mediator variable that acts as a link between the independent and independent variables.

\section{Methodology}

\subsection{Research Design}

A research design refers to the overall strategy to integrate the study's various components logically. A research design ensures that the researcher effectively addresses the research problem. The study adopted a quantitative and descriptive analysis design. The design would help in evaluating the different variables in the study. The research aimed to determine the impact of delayed disbursement of students' loans on Kenyan universities' performance. 


\subsection{Sampling Procedure}

This research used random sampling to obtain a more scientific result that could be used as a subset of the entire population. Using Kothari's (2004) formula, 196 respondents were selected through random sampling from an approximate population of 15,250 students awarded HELB loan in Kenyatta University. The study target those students who are HELB loan beneficiaries to determine if the loan delay affects academic performance. The study used the findings from those who experienced loan delay and those who did not have a loan delay to examine the impact on academic performance.

\subsection{Data Collection Method}

Data collection was performed with the help of questionnaires. A well-structured set of questionnaires was developed in line with the research objectives.

\subsection{Data Analysis}

All the questionnaires were collected and the responses were coded in an excel spreadsheet. The data was cleaned and exported to $\mathrm{R}$ for detailed analysis. In the analysis, descriptive statistics were used to present the analysis. Regression analysis was also adopted to understand the relationship between different variables.

\subsection{Validity and Reliability}

Validity refers to the integrity and application of the analytical methods used in research and the precision in which the findings accurately reflect the data. On the other hand, reliability implies consistency within the employed analytical procedures. Both validity and reliability tests were performed on the collected data. The Cronbach alpha was used to test for validity and reliability.

\section{Data Analysis and Findings}

\subsection{Measurement Scales}

According to Trochim (2007), the reliability and validity of collected data affect the quality/accuracy of conclusions made. The reliability and validity of the scales were first checked to ensure that the data collected with this tool would lead to quality conclusions.

\subsubsection{Reliability}

Reliability was assessed using Cronbach alpha, which is the internal consistency level for each of the constructs. According to (Rufina 2015), a value of Cronbach alpha greater or equal to 0.8 is acceptable by the thumb rule. For all the four constructs used. The Cronbach alpha values meet this threshold, which means that there is high internal consistency for these constructs, as shown in Tab. 1.

Table 1. Construct Reliability

\begin{tabular}{ll}
\hline Construct & Cronbach alpha \\
\hline Importance of HELB loans & 0.91 \\
Effect on Class Attendance & 0.86 \\
Effect Course/Units Registration & 0.88 \\
Effect Personal Expenses & 0.9 \\
\hline
\end{tabular}

\subsubsection{Validity}

According to Mohajan (2017), reliability doesn't imply validity. It only tells us that the scale is consistent in measuring the attributes. Therefore, the measurement scale has to be reliable in measuring the correct thing (hypothesized relationships). A confirmatory factor analysis was therefore used to assess the validity of the measurement scale. A chi-square test of fit comparing the hypothesized model and the baseline model is not significant at a $5 \%$ level $(\chi(97)=106.785)$ ), which means that the model fits the data. (Brown, 2015). The CFI and TLI index is above the recommended 0.8 , which means that data from this scale is valid, as shown in Tab. 2 below. 
Table 2. Construct Validity

\begin{tabular}{ll}
\hline index/statistic & Value \\
\hline Test statistic & 88.871 \\
Degrees of freedom & 96 \\
P-value & 0.684 \\
Comparative Fit Index (CFI) & 1 \\
Tucker-Lewis Index (TLI) & 1.003 \\
\hline
\end{tabular}

\subsection{Exploratory Data Analysis}

An exploratory data analysis was conducted using graphical representation to give an overview of the variable patterns. The dataset is well balanced across gender, with $58.2 \%$ male and $41.8 \%$ female. Conversely, most respondents were aged between 18 and 24 years (43.9\%); there are very few respondents of advanced age, as seen on the age bar graph in Fig. 2 below.

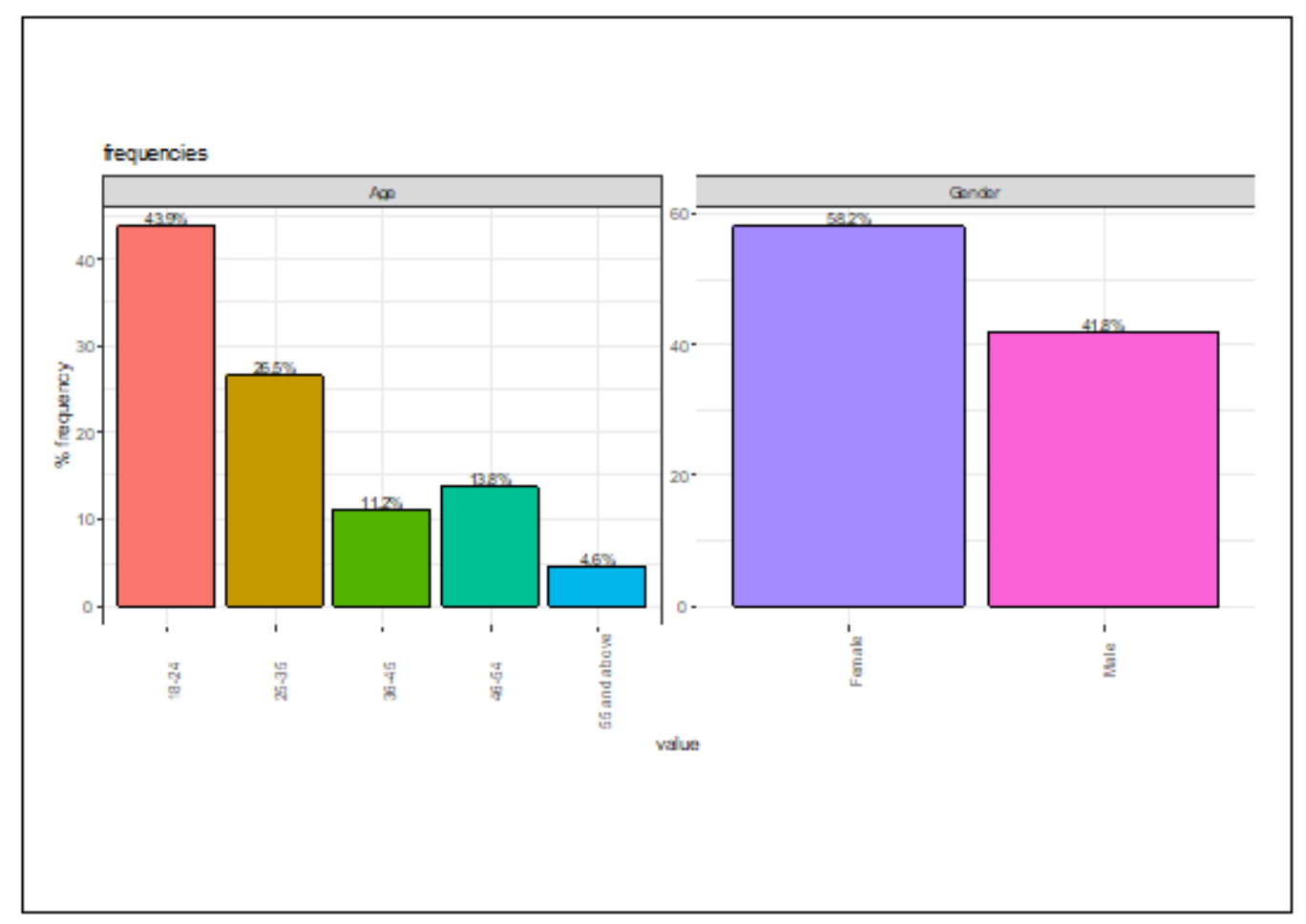

Figure 2. Background Information

There are $17 \%$ of respondents who experienced delays in HELB loan disbursements. $29.4 \%$ experienced delays once, $38.2 \%$ experience it twice, and $32.4 \%$ experienced more than twice, as shown in Fig. 3. 


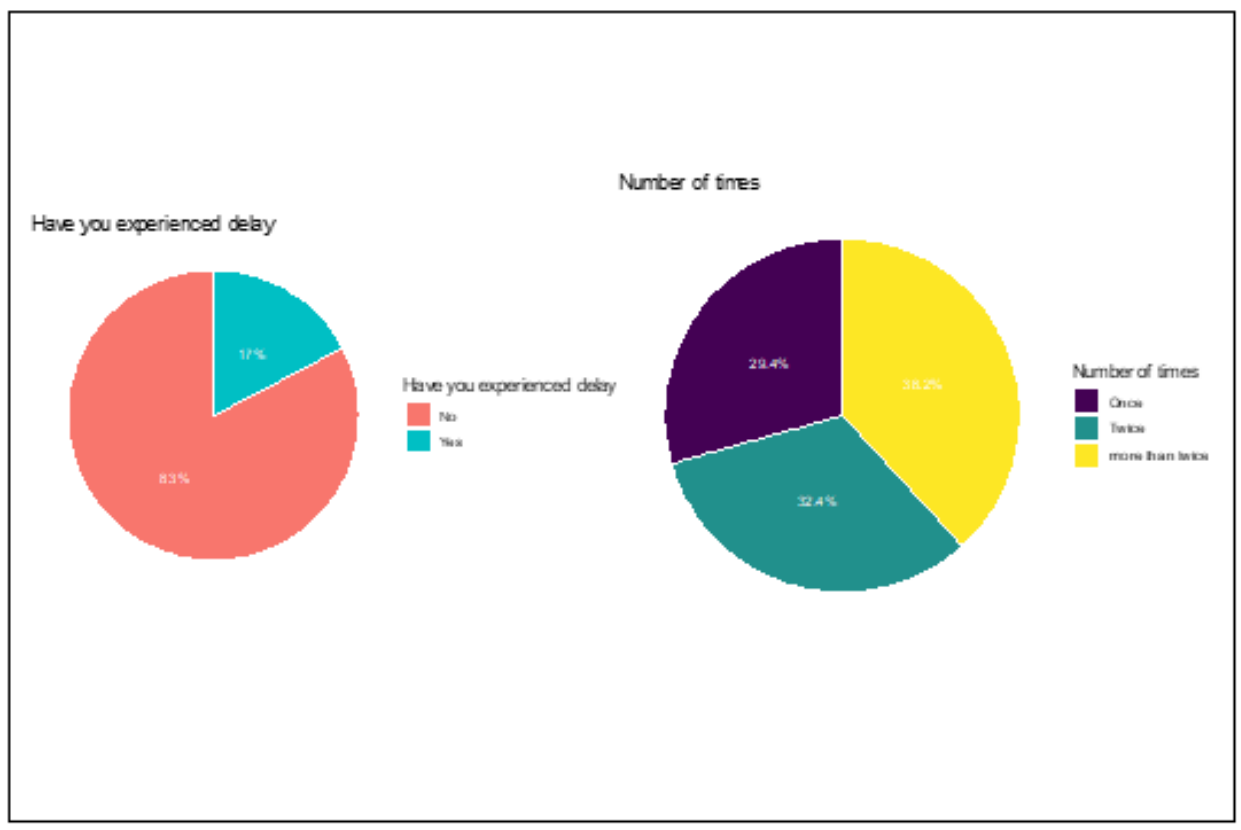

Figure 3. Delays

\subsubsection{Importance of HELB Loans}

For construct "Importance of HELB loans," all the items show a similar distribution pattern with a significant number of terming HELB loans as important to them, $16.32 \%$ of the respondents agreed that HELB allows them to work less during campus life, $16.83 \%$ agreed that it helps them purchase class materials. Conversely, $18.37 \%$, $10.71 \%, 14.79 \%$ agreed that HELB loans help them with family care, living expenses, and payment of tuition fees, respectively, as shown in Fig. 4.

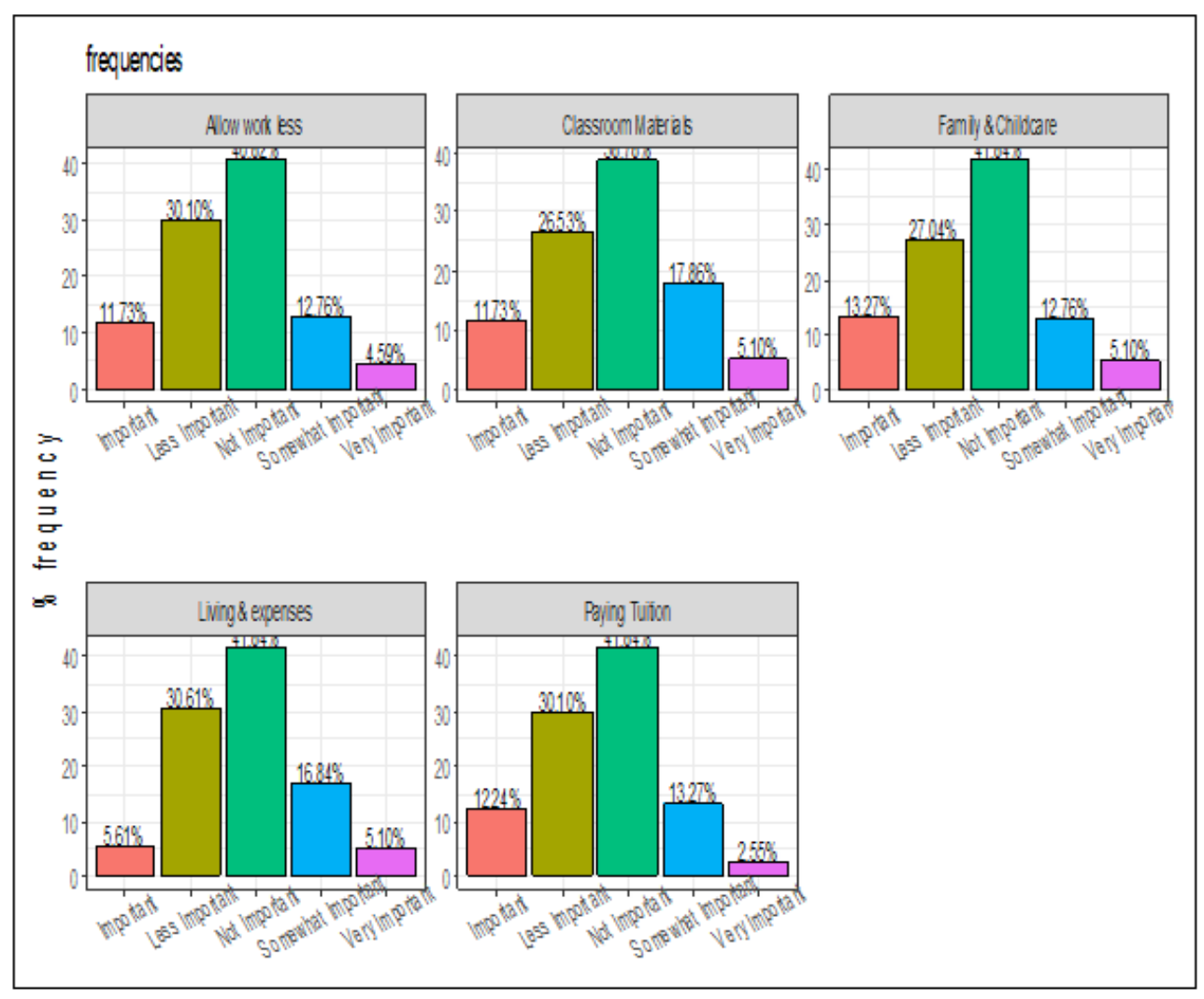

Figure 4. Importance of HELB loans 


\subsubsection{Performance}

In Fig. 5 below, 1.02\% have their current grade as a first-class, while $52 \%$ have a second class upper while $42.3 \%$ have second class lower. Only $4.59 \%$ had a pass.

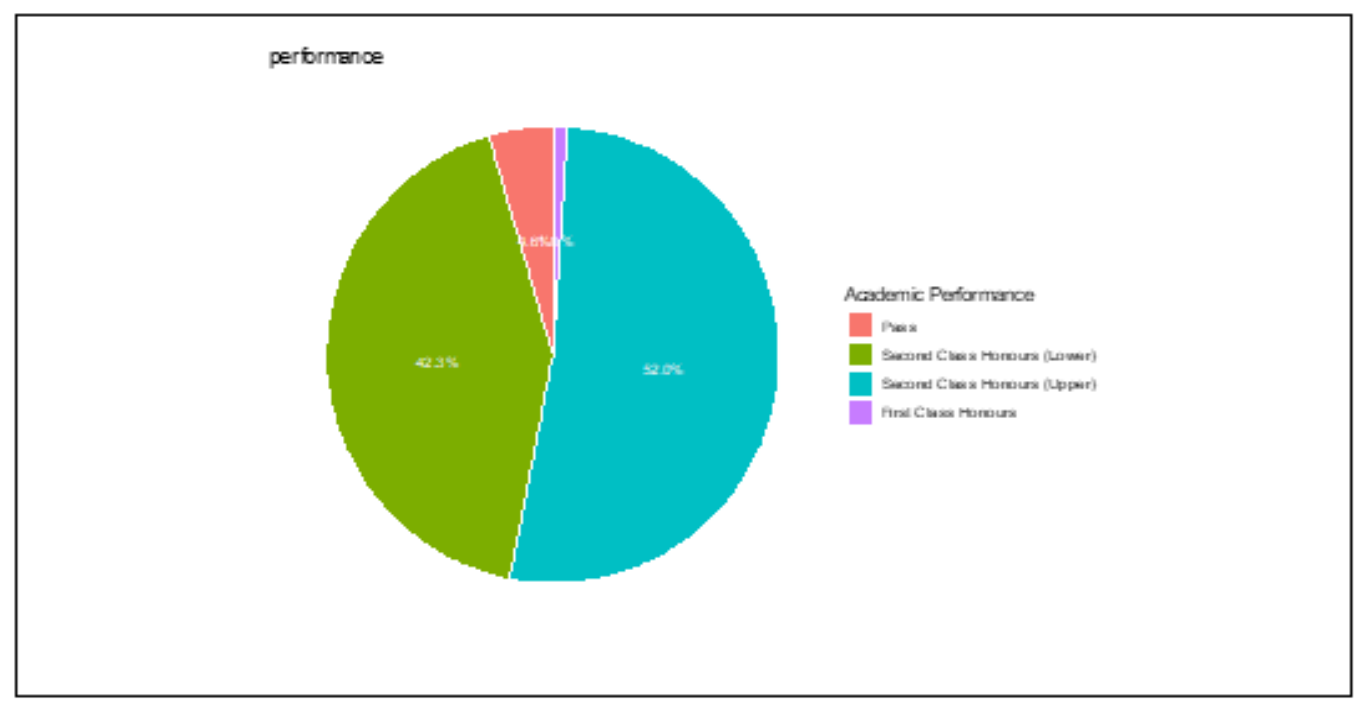

Figure 5. Performance

\subsubsection{Regression}

A path analysis approach was used to analyze the data. The dependent variable delay is a binary variable: 1 for people who have never experienced loan delays and 0 for those who have experienced loan delays. A chi-square test of fit comparing the hypothesized model and the baseline model is not significant at a $5 \%$ level $(\chi(36)=$ $29.629, \mathrm{p}=.764)$, which means that the model fits the data. The hypothesized model fits the dataset, as shown in Tab. 3.

Table 3. Regression

\begin{tabular}{ll}
\hline index/statistic & Value \\
\hline Test statistic & 29.629 \\
Degrees of freedom & 36 \\
P-value & 0.764 \\
Comparative Fit Index (CFI) & 1 \\
Tucker-Lewis Index (TLI) & 1.005 \\
\hline
\end{tabular}

\subsubsection{Regression Paths}

Four regression paths of inters were executed. The regression estimate for Class Attendance is 1.516, which means, on average, class attendance for the group which didn't experience loan delay had a significantly higher-class attendance compared to the other group. $(B=1.516, p<0.001)$. Conversely, for unit registration, the average for the group that did not experience delay is significantly high at a 0.5 level of significance compared to the other group. The same applies to personal Expenses and performance. Tab.4 is a graphical representation of the path model.

Table 4. Regression paths

\begin{tabular}{lllll}
\hline & Estimate & Std.Err & $\boldsymbol{z}$-value & $\boldsymbol{P}(>|z|)$ \\
\hline Class Attendance Delay & 1.516 & 0.203 & 7.479 & $<0.001$ \\
Units Registration Delay & 1.468 & 0.202 & 7.28 & $<0.001$ \\
Personal Expenses Delay & 1.332 & 0.195 & 6.817 & $<0.001$ \\
Performance $\sim$ Delay & 0.647 & 0.104 & 6.236 & $<0.001$ \\
\hline
\end{tabular}




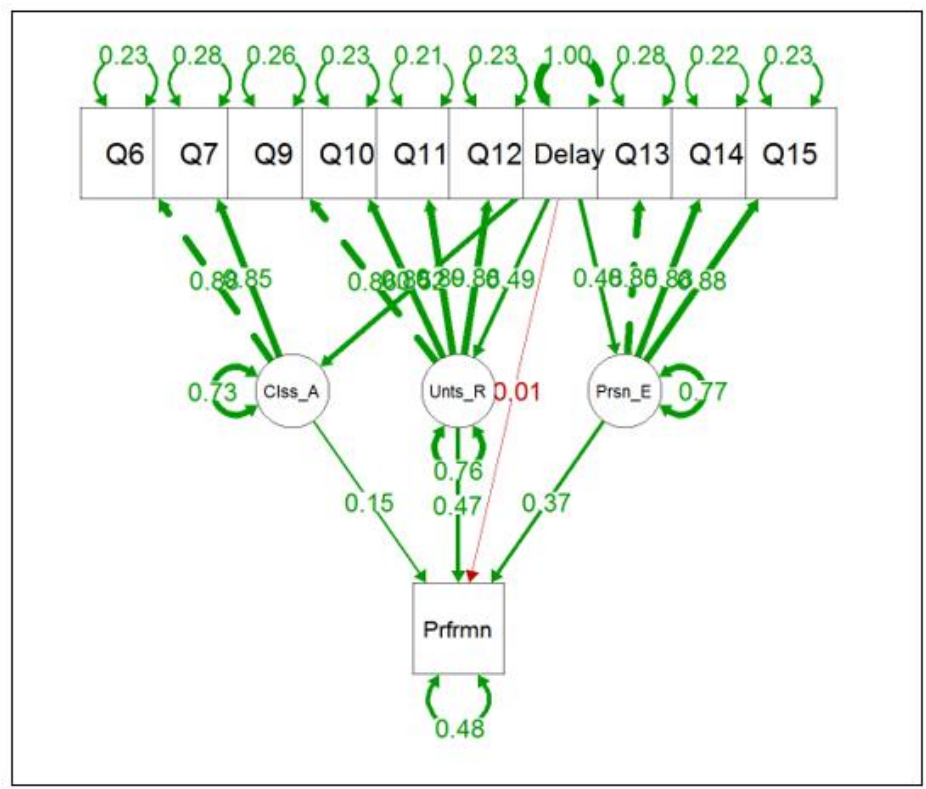

Figure 6. A path model

\subsubsection{Path Analysis}

A path analysis model was run using Lavaan R, as shown in Fig.6, which uses the maximum likelihood estimation method and NLMINB optimization method model.

\subsubsection{Model Fit}

\section{Overview of the model fit test}

In this study, three models were considered to gauge how good our sample data; they include a saturated model, Baseline model, and the observed model. The saturated model is termed as the reasonably best-fitting model while the baseline model is the reason the worst fitting model (Klein, 2010)

\section{Saturated model}

This is the best fitting model (Perfect fitting model), and it contains several parameters equal to the number of degrees of freedom (Badia \& Noguera, 2020). It is achieved by reproducing all means of covariance and variances of the observed variables. Being the best fitting model, we use it as a reference to know how good the other models fit our data; in other words, how far our observed model falls from the best scenario possible. The difference between the log-likelihood. According to (Eduardo García Portugués et al., 2018). Another exciting feature of the saturated model is that it has a likelihood equal to 1, this means that log-likelihood (also denoted as $\log l i k)$ is 0 and in turn -2loglik becomes zero too. The difference between the two models is called deviance, which is calculated as.

Deviance $=-2 \log l i k($ Observed model $)-2 \log$ lik (saturated model $)$

$$
=-2 \operatorname{loglik}(\text { Observed model })+2 \log \text { lik (saturated model) }
$$

But we already know that $-2 \log l i k$ (saturated model) $=0$; therefore

Deviance $=-2 \operatorname{loglik}($ Observed model $)$

Large deviance would mean that our model is far from the best fitting (close to the worst fitting model) model; therefore, it does not fit a good model. The assumption that Deviance follows a chi-square distribution allows us to use a chi-square test of fit to determine whether the deviance is large than expected. The null hypothesis is that the observed model is not significantly different from the expected model.

From the above explanations, we do not need to implement the saturated model because we know it's -2loglik is always 0; this is why Lavaan does not print its results.

\section{Baseline model}

This is the worst fitting model (Klein, 2010); it is obtained by restricting covariances of all the observed 
variables to 0 (assuming that the observed variables are not related at all). It is also called the null model. For this case, the Baseline model differs significantly from the saturated model at $5 \%$ levels. $(\chi(55)=2125.770, \mathrm{p}$ $<0.001$ ) as shown in Tab. 5 .

Table 5. Baseline Model

\begin{tabular}{ll}
\hline Statistic & Value \\
\hline Test statistic & 2125.770 \\
Degrees of freedom & 55 \\
P-value (Chi-square) & $<0.01$ \\
\hline
\end{tabular}

\section{Observed model/User Model}

This is our realized model or the model we are interested in. It also differs significantly from the saturated model at the $5 \%$ level. $(\chi(39)=632.755, \mathrm{p}<0.001)$. This means that the path model does not fit our data well, as shown in Tab. 6 below.

Table 6. Observed/User Model

\begin{tabular}{ll}
\hline Statistic & Value \\
\hline Test statistic & 632.755 \\
Degrees of freedom & 39 \\
P-value (Chi-square) & $<0.01$ \\
\hline
\end{tabular}

\section{Fit indexes}

According to practical significance, as the sample size increases, the statistical power increase. The tests start to detect even small deviances (Roger, 1996); therefore, it is useful to compute fit indexes. The Tab.7, TLI and CFI indices are 0.713 and 0.596 , respectively. The values are less than the recommended value equal to .90 (Bentler, 1990); equally, the RMSEA is significantly above the recommended value .05 .

Table 7. Fit Indexes

\begin{tabular}{lc}
\hline Index & Value \\
\hline Comparative Fit Index (CFI) & 0.713 \\
Tucker-Lewis Index (TLI) & 0.596 \\
\hline
\end{tabular}

\subsubsection{Mediation}

\section{Direct Impact}

For this analysis, HELB loan delay does not directly impact student performance at a $5 \%$ level of significance ( $\beta$ $=-0.018, \mathrm{p}=.858$ ).

\section{Indirect effect}

The path through class attendance is significant at a $5 \%$ level $(\beta=.105, \mathrm{p}=.034)$, which means that HELB loan delay affects student performance through class attendance. On average, for students who have experience HELB loan delays, the impact on performance implied through class attendance is .105 higher than for students who have never experienced loan delays.

The path through Units/course registration is significant at $5 \%(\beta=.319, \mathrm{p}<0.001)$, which means that HELB loan delay affects student performance through Units/course registration. On average, for students who have experience HELB loan delays, the implied impact on performance through class attendance is .319 higher than for students who have never experienced loan delays.

The path through personal expenditure is significant at $5 \%(\beta=.242, \mathrm{p}<0.001)$, which means that HELB loan delay affects student performance through personal expenditure. On average, for students who have experience HELB loan delays, the implied impact on performance through personal expenditure is .242 higher than for students who have never experience loan delays.

\section{Total effect}

The overall total effect (direct and indirect effect) is significant at $5 \%$ level $(\beta=.647, p<0.001)$. This satisfies the hypothesis that HELB loan delay impacts performance, as shown in Tab. 8 below. 
Table 8. Total Effect

\begin{tabular}{lllll}
\hline & Estimate & Std.Err & z-value & $\boldsymbol{P}(>|z|)$ \\
\hline Through class attendance & 0.105 & 0.049 & 2.123 & 0.034 \\
Through Units/course registration & 0.319 & 0.059 & 5.368 & 0.000 \\
Through personal expenditure & 0.242 & 0.053 & 4.56 & 0.000 \\
Total & 0.647 & 0.086 & 7.512 & 0.000 \\
\hline
\end{tabular}

\section{Discussion}

The data evaluated reveals how delayed loan disbursement impacts class attendance, which eventually affects the students' performance. Even though there is little literature on the impact of delayed loans on class attendance, the current studies provide a foundation for a detailed evaluation of how delayed loans affect the beneficiaries' patterns of attending classes. The studies by Moore (2004) linked class attendance to performance, and the findings showed that those courses which were well-attended eventually displayed better results. Hence, delayed loans that limit students from attending classes are more likely to negatively affect their final performance. Furthermore, the current findings support the findings by Dynarski (2000), which found that increased funding students had a significant impact on class attendance.

The data evaluated shows that course registration has a significant impact on student performance. Course registration allows the student to study for the course and eventually undertake examinations. Students who fail to register for their courses or are forced to drop due to financial challenges eventually lag behind in their studies. Also, this reduces their morale and ultimately impact their results. The current findings resonate with the study done by Gurantz (2016), which identified various economic factors that affect course registration. The factors, which included budget cuts and unemployment, were vital in course registration. Therefore, there is a need to enhance loan disbursement timelines to ensure students register for the courses on time to avoid courses' last-minute cancellations.

Personal expenses play a crucial role in ensuring that students get their basic needs and have ample time to focus on their studies. Personal expenses are related to basic needs, such as food, clothing, shelter, and transport costs. When students strain in meeting these expenses, they eventually lose focus in their studies. This forces some students to seek employment during their free time, thus reducing their study time. The current findings reveal that personal expenses are critical to student college life, and delayed loans result in frustrations and agony. The findings confirm the study by Young (2020), which revealed that student loans are not only crucial in paying tuition fees but also in settling expenses such as housing and supplies. This shows that delayed loans would limit the students from meeting their expenses, thus impacting their performance.

\section{Conclusion}

\subsection{Summary}

The current study sought to evaluate the impact of delayed loan disbursement on students' academic performance in Kenya's higher education. The Kenyan government began a program to fund higher education in the early 1980s. However, the program was highly criticized due to poor administration, high cost, and low loan recoveries. As a result, the Higher Education Loans Board (HELB) was enacted in 1995 to address some of these challenges. Despite the increased allocation of funds to HELB, many students still miss out on the loans due to the increased enrollment in the Kenyan colleges and universities. Also, the institution is still struggling with low loan recoveries. The current research evaluated the impact of delayed loans on various factors that impact student performance. The literature evaluated reveals that delayed loan disbursements have a significant effect on the performance of the students. The study has shown that delayed loan disbursement significantly impacts student performance through the mediator variables of unit registration, personal expenses, and class attendance.

\subsection{Policy Implication}

The results from the study reveal significant challenges facing students who benefit from government support through HELB. In light of these, this study recommends a need for the government policy to ensure that adequate budgetary allocations are made to the Higher Education Loans Board to facilitate the students' timely disbursement of the loans. HELB depends on the government for all the funds it allocates to the students; therefore, any government budgetary delays will negatively impact them. There is also a need for the government policy to facilitate the collaboration between the college and university administrations, which allows for negotiations whenever there are students' loan delays. This will enable the students to register for their courses and attend classes even if the funds have not yet been disbursed. It will be the role of HELB to give 
assurance to the administration of the students whose funds are still under the process.

\section{References}

Abdul, M. (2015). Sustainability of Higher Education Students' Loan Scheme (HESLS) in Tanzania. European Journal of Business and Management. Retrieved from http://repository.businessinsightz.org/handle/20.500.12018/533

Aden, A. A., Yahye, Z. A., \& Dahir, A. M. (2013). The effect of student's attendance on academic performance: a case study at Simad university Mogadishu. Academic Research International, 4(6), 409.

Adzido, R. Y. N., Dzogbede, O. E., Ahiave, E., \& Dorkpah, O. K. (2016). Assessment of family income on academic performance of tertiary students: The case of Ho Polytechnic, Ghana. International Journal of Academic Research in Accounting, Finance and Management Sciences, 6(3), 154-169. https://doi.org/10.6007/IJARAFMS/v6-i3/2221

Albrecht, D., \& Ziderman, A. (1992). Funding Mechanisms for Higher Education: Financing for Stability, Efficiency, and Responsiveness. World Bank Discussion Papers. World Bank, 1818 H Street, NW, Washington, DC 20433.

Alexander, V., \& Hicks, R. E. (2016). Does class attendance predict academic performance in first year psychology tutorials. International Journal of Psychological Studies, 8(1), 28-32. https://doi.org/10.5539/ijps.v8n1p28

Badia, G., \& Noguera, C. (2020). Saturated models of first-order many-valued logics. Logic Journal of the IGPL. https://doi.org/10.1093/jigpal/jzaa027

Bentler, P. M. (1990). Comparative fit indexes in structural models. Psychological Bulletin, 107(2), 238. https://doi.org/10.1037/0033-2909.107.2.238

Brown, T. A. (2015). Confirmatory factor analysis for applied research (2nd ed.). New York, NY: Guilford Press.

Chatama, Y. (2014). Financing of Higher Education: an evolution of Cost Sharing approach in Tanzania. Semantic Scholar. Retrieved from https://www.semanticscholar.org/paper/Financing-of-Higher-Education\%3A-an-evolution-of-Cost-Chatama 155343b35f3e25cebc472e5ef5539180c8a4f619d

Cooley, A. (2013). Promissory education: Reforming the federal student loan counseling process to promote informed access and to reduce student debt burdens. Conn. L. Rev, 46(1), 119. Retrieved from https://heinonline.org/HOL/LandingPage?handle=hein.journals/conlr46\&div=6\&id=\&page=

Coria, E., \& Hoffman, J. (2015). Financial aid tipping points: an analysis of aid and academic achievement at a California community college. Community College Journal of Research and Practice, 40(2), 160-170. https://doi.org/10.1080/10668926.2014.993441

Curs, B., \& Harper, C. (2012). Financial Aid and First-Year Collegiate G.P.A.: A Regression Discontinuity Approach. The Review of Higher Education, 35(4), 627-649. https://doi.org/10.1353/rhe.2012.0040

Dey, I. (2018). Class attendance and academic performance: A subgroup analysis. International Review of Economics Education, 28, 29-40. https://doi.org/10.1016/j.iree.2018.03.003

Dynarski, S. (2000). Hope for Whom? Financial Aid for the Middle Class and Its Impact on College Attendance. National Tax Journal, 53(3), 629-661. https://doi.org/10.3386/w7756

Fosnacht, K., \& Dong, Y. (2013, November). Financial stress and its impact on first-year students' college experiences. Association for the Study of Higher Education Annual Conference.

Fujiwara, K. (2013). The Influence of Late Registration on the Academic Performance of College-Ready Students.

García-Portugués, E., Álvarez-Liébana, J., Álvarez-Pérez, G., \& González-Manteiga, W. (2019). A goodness-of-fit test for the functional linear model with functional response. arXiv preprint arXiv:1909.07686. https://doi.org/10.1111/sjos.12486

Gillies, D. (2017). Human capital theory in education. Encyclopedia of Educational Philosophy and Theory, 1-5. https://doi.org/10.1007/978-981-287-588-4_254

Gurantz, O. (2016). Who Loses Out? Registration Order, Course Availability, and Student Behaviors in Community College. The Journal of Higher Education, 86(4), 524-563. 
https://doi.org/10.1080/00221546.2015.11777374

Hale, J. M., \& Bray, N. J. (2011). The impact of registration timing on student performance. Community College Journal of Research and Practice, 35(7), 556-573. https://doi.org/10.1080/10668920802289984

Holden, L., \& Biddle, J. (2017). The introduction of human capital theory into education policy in the United States. History of Political Economy, 49(4), 537-574. https://doi.org/10.1215/00182702-4296305

Hu, L., \& Bentler, P. M. (1999). Cutoff criteria for fit indexes in covariance structure analysis: Conventional criteria versus new alternatives. Structural Equation Modeling, 6, 1-55. https://doi.org/10.1080/10705519909540118

Jianguo, W., \& Rong, W. (2011). Student Loan Reform in China: Problems and challenges. Financing Higher Education and Economic Development in East Asia, 145. https://doi.org/10.22459/FHEEDEA.11.2011.07

Joensen, J. S., \& Mattana, E. (2019). Student Aid Design, Academic Achievement, and Labor Market Behavior: Grants or Loans?. Academic Achievement, and Labor Market Behavior: Grants or Loans.

Johnstone, D. B. (2015). Making Student Loans Work in Africa. International Journal of African Higher Education, 2. https://doi.org/10.6017/ijahe.v2i1.9256

Kallison, J., \& Cohen, P. (2010). A New Compact for Higher Education: Funding and Autonomy for Reform and Accountability. Innovative Higher Education, 35(1), 37-49. https://doi.org/10.1007/s10755-009-9123-2

Kline, R. B. (2010). Principles and practice of structural equation modeling (3rd ed.). New York, NY: Guilford Press.

Kothari, C. R. (2004). Research methodology: Methods and techniques. New Age International.

Landin, M., \& Pérez, J. (2015). Class attendance and academic achievement of pharmacy students in a European University. Currents in Pharmacy Teaching and Learning, 7(1), 78-83. https://doi.org/10.1016/j.cptl.2014.09.013

Latif, E., \& Miles, S. (2013). Class Attendance and Academic Performance: A Panel Data Analysis. Economic Papers: A Journal of Applied Economics and Policy, 32(4), 470-476. https://doi.org/10.1111/1759-3441.12054

Malkanthie, A. (2015). Structural Equation Modeling with AMOS.

Mangold, W., Bean, L., Adams, D., Schwab, W., \& Lynch, S. (2002). Who Goes Who Stays: An Assessment of the Effect of a Freshman Mentoring and Unit Registration Program on College Persistence. Journal Of College Student Retention: Research, Theory \& Practice, 4(2), 95-122. https://doi.org/10.2190/CVET-TMDM-CTE4-AFE3

Marian, W., Beckie, S., \& Andrea, F. (2012). The Parent Loan Trap. Chronicle of Higher Education. Retrieved from https://eric.ed.gov/?id=EJ990508

Martín, P., Potočnik, K., \& Fras, A. B. (2017). Determinants of students' innovation in higher education. Studies in Higher Education, 42(7), 1229-1243. https://doi.org/10.1080/03075079.2015.1087993

Marx, B., \& Turner, L. (2019). Student Loan Nudges: Experimental Evidence on Borrowing and Educational Attainment. American Economic Journal: Economic Policy, 11(2), 108-141. https://doi.org/10.1257/pol.20180279

Mohajan, H. K. (2017). Two criteria for good measurements in research: Validity and reliability. Annals of Spiru Haret University. Economic Series, 17(4), 59-82. https://doi.org/10.26458/1746

Moore, R. (2004). Does Improving Developmental Education Students' Understanding of the Importance of Class Attendance Improve Students' Attendance and Academic Performance?. Research and Teaching in Developmental Education, 20(2), 24-39. Retrieved from https://www.jstor.org/stable/42802197?seq=1

Msigwa, F. M. (2016). Widening participation in higher education: a social justice analysis of student loans in Tanzania. Higher Education, 72(4), 541-556. https://doi.org/10.1007/s10734-016-0037-5

Nyahende, V. (2013). The Success of Students' Loans in Financing Higher Education in Tanzania. Higher Education Studies, 3(3), 47-61. https://doi.org/10.5539/hes.v3n3p47

Nyakunga, R. Z. (2011). Cost sharing and academic performance: A Case of Mzumbe University: Morogoro Main Campus, Tanzania (Master's thesis).

Oketch, M. (2016). Financing higher education in sub-Saharan Africa: some reflections and implications for 
sustainable development. Higher Education, 72(4), 525-539. https://doi.org/10.1007/s10734-016-0044-6

Otieno, W. (2004). Student loans in Kenya: Past experiences, current hurdles, and opportunities for the future. Journal of Higher Education in Africa/Revue de l'enseignementsupérieuren Afrique, 75-99.

Rosaroso, R. (2015). USING RELIABILITY MEASURES IN TEST VALIDATION.

Sandy, B., \& Kathleen, P. (2012). Trends in Student Aid, 2012. Trends in Higher Education Series. College Board Advocacy \& Policy Center. Retrieved from https://eric.ed.gov/?id=ED536570

Schmulian, A., \& Coetzee, S. (2011). Class absenteeism: reasons for non-attendance and the effect on academic performance. Accounting Research Journal, 24(2), 178-194. https://doi.org/10.1108/10309611111163718

Shriner, K. N. (2014). Late registration: Continued impact on student success. Community College Journal of Research and Practice, 38(6), 588-591. https://doi.org/10.1080/10668926.2013.790857

Sieg, H., \& Wang, Y. (2018). The impact of student debt on education, career, and marriage choices of female lawyers. European Economic Review, 109, 124-147. https://doi.org/10.1016/j.euroecorev.2017.05.009

Singell, L. (2004). Come and stay a while: does financial aid effect retention conditioned on enrollment at a large public university?. Economics Of Education Review, 23(5), 459-471.

https://doi.org/10.1016/j.econedurev.2003.10.006

Smith, A., Street, M., \& Olivarez, A. (2010). Early, Regular, And Late Registration And Community College Student Success: A Case Study. Community College Journal of Research and Practice, 26(3), 261-273. https://doi.org/10.1080/106689202317245455

Smith, M. F. (2014). The relationship between registration time and major status and academic performance and retention of first-time-in-college undergraduate students at a four-year, public university. University of North Texas. Retrieved from https://www.semanticscholar.org/paper/The-Relationship-Between-Registration-Time-and-and-Smith/f98b4 $8395217 \mathrm{c} 35 \mathrm{~b} 6 \mathrm{~d} 59 \mathrm{~d} 9103 \mathrm{~d} 6355 \mathrm{f} 9 \mathrm{fa} 5 \mathrm{cc} 8 \mathrm{eb}$

Stanca, L. (2006). The effects of attendance on academic performance: Panel data evidence for introductory microeconomics. The Journal of Economic Education, 37(3), 251-266. https://doi.org/10.3200/JECE.37.3.251-266

Tangkitvanich, S., \& Manasboonphempool, A. (2010). Evaluating the Student Loan Fund of Thailand. Economics of Education Review, 29(5), 710-721. https://doi.org/10.1016/j.econedurev.2010.04.007

Thatcher, A., Fridjhon, P., \& Cockcroft, K. (2007). The relationship between lecture attendance and academic performance in an undergraduate psychology class. South African Journal of Psychology, 37(3), 656-660. https://doi.org/10.1177/008124630703700316

Trochim, W. (2007). The Research Methods Knowledge Base.

Weaver, A. E. (2013). The Relationship Between Students' Financial Responsibility for College and Levels of Academic Motivation and Success. Doctoral dissertation, Ashland University.

Woodhall, M. (1991). Student Loans in Higher Education: 2. Asia. Report of an IIEP Educational Forum. IIEP Dissemination Programme, Educational Forum Series, No. 2.

Young, J. (2020). How to Use Student Loans for Living Expenses. Credible. Retrieved from https://www.credible.com/blog/student-loans/student-loans-living-expenses/

\section{Copyrights}

Copyright for this article is retained by the author(s), with first publication rights granted to the journal.

This is an open-access article distributed under the terms and conditions of the Creative Commons Attribution license (http://creativecommons.org/licenses/by/4.0/). 